\title{
Front Matter: Volume 7927
}

, "Front Matter: Volume 7927," Proc. SPIE 7927, Advanced Fabrication Technologies for Micro/Nano Optics and Photonics IV, 792701 (29 March 2011); doi: 10.1117/12.891639

SPIE. Event: SPIE MOEMS-MEMS, 2011, San Francisco, California, United States 


\section{PROCEEDINGS OF SPIE}

\section{Advanced Fabrication Technologies for Micro/Nano Optics and Photonics IV}

Winston V. Schoenfeld

Jian Jim Wang

Marko Loncar

Thomas J. Suleski

Editors

25-26 January 2011

San Francisco, California, United States

Sponsored and Published by

SPIE 
The papers included in this volume were part of the technical conference cited on the cover and title page. Papers were selected and subject to review by the editors and conference program committee. Some conference presentations may not be available for publication. The papers published in these proceedings reflect the work and thoughts of the authors and are published herein as submitted. The publisher is not responsible for the validity of the information or for any outcomes resulting from reliance thereon.

Please use the following format to cite material from this book:

Author(s), "Title of Paper," in Advanced Fabrication Technologies for Micro/Nano Optics and Photonics IV, edited by Winston V. Schoenfeld, Jian Jim Wang, Marko Loncar, Thomas J. Suleski, Proceedings of SPIE Vol. 7927 (SPIE, Bellingham, WA, 2011) Article CID Number.

ISSN 0277-786X

ISBN 9780819484642

Published by

SPIE

P.O. Box 10, Bellingham, Washington 98227-0010 USA

Telephone +1 3606763290 (Pacific Time) · Fax +1 3606471445

SPIE.org

Copyright (@ 2011, Society of Photo-Optical Instrumentation Engineers

Copying of material in this book for internal or personal use, or for the internal or personal use of specific clients, beyond the fair use provisions granted by the U.S. Copyright Law is authorized by SPIE subject to payment of copying fees. The Transactional Reporting Service base fee for this volume is $\$ 18.00$ per article (or portion thereof), which should be paid directly to the Copyright Clearance Center (CCC), 222 Rosewood Drive, Danvers, MA 01923. Payment may also be made electronically through CCC Online at copyright.com. Other copying for republication, resale, advertising or promotion, or any form of systematic or multiple reproduction of any material in this book is prohibited except with permission in writing from the publisher. The CCC fee code is 0277-786X/11/\$18.00.

Printed in the United States of America.

Publication of record for individual papers is online in the SPIE Digital Library.

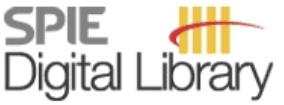

SPIEDigitalLibrary.org

Paper Numbering: Proceedings of SPIE follow an e-First publication model, with papers published first online and then in print and on CD-ROM. Papers are published as they are submitted and meet publication criteria. A unique, consistent, permanent citation identifier (CID) number is assigned to each article at the time of the first publication. Utilization of CIDs allows articles to be fully citable as soon as they are published online, and connects the same identifier to all online, print, and electronic versions of the publication. SPIE uses a six-digit CID article numbering system in which:

- The first four digits correspond to the SPIE volume number.

- The last two digits indicate publication order within the volume using a Base 36 numbering system employing both numerals and letters. These two-number sets start with 00, 01, 02, 03, 04 , 05, 06, 07, 08, 09, OA, OB ... 0Z, followed by 10-1Z, 20-2Z, etc.

The CID number appears on each page of the manuscript. The complete citation is used on the first page, and an abbreviated version on subsequent pages. Numbers in the index correspond to the last two digits of the six-digit CID number. 


\title{
Contents
}

\author{
ix Conference Committee \\ xi Lateral spread of MEMS WDM technologies (Plenary Paper) [7930-202] \\ H. Toshiyoshi, The Univ. of Tokyo (Japan) \\ xxiii Toy Story: what I have learned from playing with toys about the physics of living cells \\ (Plenary Paper) [7929-203] \\ R. H. Austin, Princeton Univ. (United States)
}

\section{SESSION 1 NANOFABRICATION I: PHOTONIC NANOSTRUCTURES}

792704 Photolithographic fabrication of slot waveguides (Invited Paper) [7927-03]

A. Spott, R. Ding, T. Baehr-Jones, Univ. of Washington (United States); W.-J. Kim, Seattle Univ. (United States); X. Xiong, R. Bojko, Univ. of Washington (United States); J.-M. Fedeli, M. Fournier, CEA-LETI (France); M. Hochberg, Univ. of Washington (United States)

792705 Environmentally responsive active optics based on hydrogel-actuated deformable mirror arrays (Invited Paper) [7927-04]

P. Kim, L. D. Zarzar, M. Khan, M. Aizenberg, J. Aizenberg, Harvard Univ. (United States)

\section{SESSION 2 3D LITHOGRAPHY}

792706 Advanced fabrication methods for 3D meta-optics (Invited Paper) [7927-05]

E. G. Johnson, M. K. Poutous, Z. A. Roth, P. Srinivasan, A. J. Pung, Y. O. Yilmaz, The Univ. of North Carolina at Charlotte (United States)

792707 A new fabrication method for 3D Si-based photonic crystal structures [7927-06] M. Taysing-Lara, G. Dang, W. Zhou, U.S. Army Research Lab. (United States)

792709 Selective inhibition of polymerization enables sub-diffraction optical lithography [7927-08] B. Harke, Istituto Italiano di Tecnologia (Italy); P. Bianchini, Istituto Italiano di Tecnologia (Italy) and Univ. degli Studi di Genova (Italy); F. Anjum, F. Brandi, Istituto Italiano di Tecnologia (Italy); A. Diaspro, Istituto Italiano di Tecnologia (Italy) and Univ. degli Studi di Genova (Italy)

\section{SESSION 3 ADVANCED LITHOGRAPHY}

7927 OA On the evolution of wafer level cameras (Invited Paper) [7927-10] H. Welch, Tessera, Inc. (United States)

7927 OB Fabrication of large-area metal nanoparticle arrays by nanosphere lithography for localized surface plasmon resonance biosensors [7927-11]

R. C. Denomme, K. Iyer, M. Kreder, B. Smith, P. M. Nieva, Univ. of Waterloo (Canada) 
7927 OF Direct laser writing and applications of dielectric microstructures with low refractive index contrast [7927-15]

V. Mizeikis, Shizuoka Univ. (Japan); V. Purlys, Vilnius Univ. (Lithuania); L. Maigyte, K. Staliunas, Univ. Politècnica de Catalunya (Spain); S. Juodkazis, Swinburne Univ. of Technology (Australia)

$7927 \mathrm{OH} \quad$ 2D nanosphere lithography by using surface plasmon-enhanced optical trapping [7927-17] Y.-C. Li, C.-Y. Lin, K.-C. Chiv, C.-F. Cheang, Y.-C. Chang, S.-J. Chen, National Cheng Kung Univ. (Taiwan)

\section{SESSION 5 MICRO AND NANO-OPTICS}

7927 0J Fabrication of singulated micro-retro-reflectors for textured surfaces [7927-19]

M. K. Poutous, The Univ. of North Carolina at Charlotte (United States); M. J. Maston, S. Leibholtz, VizorNet, Inc. (United States); E. G. Johnson, The Univ. of North Carolina at Charlotte (United States)

7927 OK Freeform micromachining of an infrared Alvarez lens [7927-20]

P. J. Smilie, B. S. Dutterer, J. L. Lineberger, M. A. Davies, T. J. Suleski, The Univ. of North Carolina at Charlotte (United States)

$7927 \mathrm{OL}$ Wafer level glass optics: precision glass molding as an alternative manufacturing approach [7927-21]

M. Huenten, D. Hollstegge, F. Wang, O. Dambon, F. Klocke, Fraunhofer Institute for Production Technology (Germany)

7927 OM Manufacturing of cylindrical diffractive lens by ruling [7927-22]

J. Väyrynen, North Karelia Univ. of Applied Sciences (Finland); T. Saastamoinen, J. Mutanen, P. Pääkkönen, Univ. of Eastern Finland (Finland); K. Mönkkönen, North Karelia Univ. of Applied Sciences (Finland); M. Kuittinen, Univ. of Eastern Finland (Finland)

7927 ON Diamond milling or furning for the fabrication of micro lens arrays: comparing different diamond machining technologies [7927-23]

S. Scheiding, Fraunhofer-Institut für Angewandte Optik und Feinmechanik (Germany) and Friedrich-Schiller-Univ. Jena (Germany); A. Y. Yi, The Ohio State Univ. (United States); A. Gebhardt, R. Loose, Fraunhofer-Institut für Angewandte Optik und Feinmechanik (Germany); L. Li, The Ohio State Univ. (United States); S. Risse, R. Eberhardt, Fraunhofer-Institut für Angewandte Optik und Feinmechanik (Germany); A. Tünnermann, Fraunhofer-Institut für Angewandte Optik und Feinmechanik (Germany) and Friedrich-Schiller-Univ. Jena (Germany)

792700 Fabrication of single-mode channel waveguides via microfluidics [7927-24] S. Baig, Univ. of Miami (United States); Q. Sun, New Span Opto-Technology Inc. (United States); M. R. Wang, Univ. of Miami (United States) 
7927 OP Microfabrication of microsystem-enabled photovoltaic (MEPV) cells (Invited Paper, Green Photonics Award Paper) [7927-25]

G. N. Nielson, M. Okandan, J. L. Cruz-Campa, P. J. Resnick, Sandia National Labs. (United States); M. W. Wanlass, National Renewable Energy Lab. (United States); P. J. Clews, T. C. Pluym, C. A. Sanchez, V. P. Gupta, Sandia National Labs. (United States)

$7927 \mathrm{OQ}$ Atomic layer epitaxy of $\mathrm{TiO}_{2} / \mathrm{ZnO}$ multilayer optics using $\mathrm{ZnO}$ buffer layer for water-window x-ray [7927-26]

M. Murata, Y. Tanaka, Y. Sanjo, H. Kumagai, Osaka City Univ. (Japan); T. Shinagawa,

M. Chigane, Osaka Municipal Technical Research Institute (Japan)

7927 OS Fabrication of optical filters using multilayered porous silicon [7927-28]

N. Gaber, The American Univ. in Cairo (Egypt); D. Khalil, Ain Shams Univ. (Egypt);

A. Shaarawi, The American Univ. in Cairo (Egypt)

\section{SESSION 7 ACTIVE OPTICAL DEVICE FABRICATION}

7927 OT Microscale, printed LEDs for unusual lighting and display systems (Invited Paper, Green Photonics Award Paper) [7927-29]

R.-H. Kim, D.-H. Kim, Univ. of Illinois at Urbana-Champaign (United States); J. Xiao, Univ. of Illinois at Urbana-Champaign (United States) and Northwestern Univ. (United States); B. H. Kim, Univ. of Illinois at Urbana-Champaign (United States) and Korea Advanced Institute of Science and Technology (Korea, Republic of); B. Panilaitis, Tufts Univ. (United States); R. Ghaffari, MC10, Inc. (United States); J. Yao, Univ. of Illinois at Urbana-Champaign (United States); M. Li, Northwestern Univ. (United States) and Dalian Univ. of Technology (China); Z. Liu, Institute of High Performance Computing (Singapore); V. Malyarchuk, D. G. Kim, A.-P. Le, R. G. Nuzzo, Univ. of Illinois at Urbana-Champaign (United States); D. L. Kaplan, F. G. Omenetto, Tufts Univ. (United States); Y. Huang, Northwestern Univ. (United States); Z. Kang, Dalian Univ. of Technology (China); J. A. Rogers, Univ. of Illinois at UrbanaChampaign (United States)

7927 OU CMOS-compatible fabrication, micromachining, and bonding strategies for silicon photonics (Invited Paper) [7927-30]

J. Heck, R. Jones, M. J. Paniccia, Intel Corp. (United States)

7927 OV Single quantum dot (QD) manipulation on nanowire using dielectrophoretic (DEP) force [7927-31]

J. Kim, Korea Univ. (Korea, Republic of); S. Y. Lee, J.-K. F. Suh, Korea Institute of Science and Technology (Korea, Republic of); J. H. Park, Korea Univ. (Korea, Republic of); H. J. Shin, Korea Institute of Science and Technology (Korea, Republic of)

7927 OW DWDM DFB LD fabricated by nanoimprint process (Invited Paper) [7927-32]

W. Liu, L. Wang, Huazhong Univ. of Science and Technology (China); N. Zhou, Accelink Technologies Co., Ltd. (China); Y. Zhang, F. Qiu, Z. Xu, Huazhong Univ. of Science and Technology (China) 
7927 OY Fabrication of guided mode resonance filters on conformal surfaces [7927-34]

A. T. Cannistra, M. K. Poutous, E. G. Johnson, T. J. Suleski, The Univ. of North Carolina at Charlotte (United States)

792710 Design and fabrication of a highly off-axis binary multi-phase-level computer-generated hologram based on an effective medium approach [7927-36]

W. Freese, T. Kämpfe, E.-B. Kley, A. Tünnermann, Friedrich-Schiller-Univ. Jena (Germany)

792711 Fabrication of multispectral imaging technology driven MEMS-based micro-arrayed multichannel optical filter mosaic [7927-37]

D. Yi, Prospect Photonics Ltd. (United States); L. Kong, Ctr. for Assistive Technology and Environmental Access (United States); J. Wang, F. Zhao, Beijing Yibo Electrical-Optical Technology Co. Ltd. (China)

\section{POSTER SESSION}

792712 Ultrashort pulse induced nonlinear photo-polymerization and phase separation in liquid crystal and monomer mixtures [7927-38]

K.-C. Hsu, National Central Univ. (Taiwan); J.-H. Lin, National Taipei Univ. of Technology (Taiwan)

792713 Fabrication of hybrid optical structure by direct machining [7927-39]

T. Saastamoinen, Univ. of Eastern Finland (Finland); J. Väyrynen, North Karelia Univ. of Applied Sciences (Finland); J. Mutanen, P. Pääkkönen, T. Itkonen, Univ. of Eastern Finland (Finland); K. Mönkkönen, North Karelia Univ. of Applied Sciences (Finland); M. Kuittinen, Univ. of Eastern Finland (Finland)

792714 Laser processing and monitoring of Ag photodoped patterns in $\mathrm{GeS}_{2}$ amorphous films by dual functional laser scanning micro-processing/micro-scope system utilizing UV/VIS confocal laser scanning microscope [7927-40]

Y. Kanai, Tokai Univ. (Japan) and Genesia Corp. (Japan); Y. Murakami, Tokai Univ. (Japan) and Tsukuba Univ. of Technology (Japan); M. Wakaki, Tokai Univ. (Japan); N. Takeyama, Genesia Corp. (Japan)

792715 Hydrogen silsesquioxane (HSQ): a perfect negative tone resist for developing nanostructure patterns on a silicon platform [7927-41]

G. Singh, Univ. of Eastern Finland (Finland) and Malaviya National Institute of Technology (India); P. Stenberg, P. Vahima, M. Kuittinen, Univ. of Eastern Finland (Finland); R. P. Yadav, $\checkmark$. Janyani, Malaviya National Institute of Technology (India)

792718 In-depth fiber optic two-photon polymerization and its applications in micromanipulation [7927-44]

Y. N. Mishra, The Univ. of Texas at Arlington (United States) and Cochin Univ. of Science and Technology (India); N. Ingle, M. Pinto, S. K. Mohanty, The Univ. of Texas at Arlington (United States)

792719 Bimetallic grayscale photomasks written using optical density feedback control [7927-45] J. M. Dykes, R. Qarehbaghi, G. H. Chapman, Simon Fraser Univ. (Canada) 
7927 1B Microlithography application for production of multilevel diffractive optical elements (as a security hologram feature) [7927-47]

E. Braginets, Kievgolografia Ltd. (Ukraine) and Taras Shevchenko National Univ. of Kyiv (Ukraine); V. Kurashov, Taras Shevchenko National Univ. of Kyiv (Ukraine); S. Honcharuk, V. Girnyk, Kievgolografia Ltd. (Ukraine); S. Kostyukevych, K. Kostyukevych, V. Lashkaryov Institute of Semiconductor Physics (Ukraine)

Author Index 
Downloaded From: https://www.spiedigitallibrary.org/conference-proceedings-of-spie on 26 Apr 2023

Terms of Use: https://www.spiedigitallibrary.org/terms-of-use 


\title{
Conference Committee
}

\author{
Symposium Chair
}

Thomas J. Suleski, The University of North Carolina at Charlotte (United States)

Symposium Cochair

Harald Schenk, Fraunhofer Institute for Photonic Microsystems

(Germany)

\section{Conference Chairs}

Winston V. Schoenfeld, CREOL, The College of Optics and Photonics, University of Central Florida (United States)

Jian Jim Wang, OmniPV Inc. (United States)

Marko Loncar, Harvard University (United States)

Thomas J. Suleski, The University of North Carolina at Charlotte (United States)

\section{Program Committee}

Stefano Cabrini, Lawrence Berkeley National Laboratory (United States)

Aaron R. Hawkins, Brigham Young University (United States)

Babak Heidari, OBDUCAT AB (Sweden)

Saulius Juodkazis, Swinburne University of Technology (Australia)

Shanalyn A. Kemme, Sandia National Laboratories (United States)

Ernst-Bernhard Kley, Friedrich-Schiller-Universität Jena (Germany)

Stephen M. Kuebler, CREOL, The College of Optics and Photonics, University of Central Florida (United States)

Dwayne L. LaBrake, Molecular Imprints, Inc. (United States)

Akhlesh Lakhtakia, The Pennsylvania State University (United States)

Uriel Levy, The Hebrew University of Jerusalem (Israel)

Wen Liu, Accelink Technologies Co., Ltd. (China)

Robert R. McLeod, University of Colorado at Boulder (United States)

Yosuke Mizuyama, Panasonic Technologies Company (United States)

Patrick P. Naulleau, Lawrence Berkeley National Laboratory (United States)

Mahesh Pitchumani, Ostendo Technologies, Inc. (United States)

Dennis W. Prather, University of Delaware (United States)

John A. Rogers, University of Illinois at Urbana-Champaign (United States) 
Georg von Freymann, Karlsruher Institut für Technologie (Germany)

Michael P. Watts, Impattern Solutions (United States)

\section{Session Chairs}

$1 \quad$ Nanofabrication I: Photonic Nanostructures

Winston V. Schoenfeld, CREOL, The College of Optics and Photonics, University of Central Florida (United States)

2 3D Lithography

Vygantas Mizeikis, Shizuoka University (Japan)

3 Advanced Lithography

Thomas J. Suleski, The University of North Carolina at Charlotte (United States)

4 Laser-based Fabrication

Menelaos K. Poutous, The University of North Carolina at Charlotte (United States)

$5 \quad$ Micro and Nano-optics

Jian Jim Wang, OmniPV Inc. (United States)

$6 \quad$ Nanofabrication II: Growth and Deposition

Robert R. McLeod, University of Colorado at Boulder (United States)

$7 \quad$ Active Optical Device Fabrication

Ian Burgess, Harvard University (United States)

$8 \quad$ Nanofabrication III: Passive Optical Devices

Mahesh Pitchumani, Ostendo Technologies, Inc. (United States) 